Marquette University Law School

Marquette Law Scholarly Commons

Faculty Publications

Faculty Scholarship

$1-1-2010$

\title{
The Beginning of the End for Life Without Parole?
}

Michael M. O'Hear

Marquette University Law School, michael.ohear@marquette.edu

Follow this and additional works at: http://scholarship.law.marquette.edu/facpub

Part of the Law Commons

Publication Information

Published as Michael M. O'Hear, The Beginning of the End for Life Without Parole?, 23 Fed. Sent'g Rep. 1 (2010). ( 2010 by the Regents of the University of California on behalf of the Vera Institute of Justice. Copying and permissions notice: Authorization to copy this content beyond fair use (as specified in Sections 107 and 108 of the U. S. Copyright Law) for internal or personal use, or the internal or personal use of specific clients, is granted by the Regents of the University of California on behalf of the Vera Institute of Justice for libraries and other users, provided that they are registered with and pay the specified fee via Rightslink ${ }^{\oplus}$ on Caliber (http://caliber.ucpress.net/) or directly with the Copyright Clearance Center, http://www.copyright.com.

\section{Repository Citation}

O'Hear, Michael M., "The Beginning of the End for Life Without Parole?" (2010). Faculty Publications. Paper 112.

http://scholarship.law.marquette.edu/facpub/112

This Article is brought to you for free and open access by the Faculty Scholarship at Marquette Law Scholarly Commons. It has been accepted for inclusion in Faculty Publications by an authorized administrator of Marquette Law Scholarly Commons. For more information, please contact 


\section{EDITOR'S OBSERVATIONS}

\section{The Beginning of the End for Life Without Parole?}

\section{MICHAEL M. O'HEAR*}

Associate Dean for Research and Professor, Marquette Law School

Editor, Federal Sentencing Reporter

Editor, LifeSentencesBlog.com

Once rare, the sentence of life without parole has become common in the United States. In 2008 , more than 4I,000 inmates were serving LWOP sentences, more than triple the number from just sixteen years earlier. ${ }^{\mathrm{I}}$ One might think of the burgeoning LWOP population as just another sign of the severity revolution in American sentencing, but the LWOP story has its own peculiar dynamics. For instance, the LWOP sentence has been embraced-perhaps misguidedly-by death penalty opponents as a more humane alternative to capital punishment. ${ }^{2}$ But, whatever has caused legislatures increasingly to authorize LWOP and judges increasingly to impose it, it is clear that the legacy of this criminal justice experiment will be around for a long time: Many of those sentenced to LWOP today will likely still be in prison decades from now, consuming an ever-increasing share of corrections resources as they age and their health-care needs grow.

This issue of Federal Sentencing Reporter is devoted to the LWOP phenomenon. Interestingly, many of the contributors raise the question, implicitly or explicitly, of whether LWOP may be entering a period of decline. Most dramatically, the Supreme Court declared LWOP unconstitutional for most juvenile offenders in May 20I0, ${ }^{3}$ possibly inaugurating an era of more meaningful constitutional limitations on very long sentences. But, more quietly, many cash-strapped states have been developing new early-release programs in order to reduce corrections budgets, some of which hold out hope even for LWOP inmates. ${ }^{4}$ Additionally, increasing international criticism of LWOP may put further pressure on the United States to curtail its own use of the sentence. ${ }^{5}$ Finally, the slow but steady decline of the American death penalty may also diminish support for LWOP. ${ }^{6}$

In this essay, I will first consider the likelihood that these various developments will actually contribute to a decline in LWOP. In my view, none of the developments portend dramatic changes, at least regarding LWOP for adult offenders, although it is possible that LWOP will undergo a period of slow, long-term decline, much as has occurred with the death penalty. After laying out this perspective, I will then consider whether the United States ought to welcome such a period of decline.

\section{Why It Might Be the Beginning of the End for LWOP}

It is notoriously difficult to prognosticate in the area of crime and punishment. In the early I990s, who would have guessed that crime rates were about to fall precipitously, but that sentencing policies would only grow harsher and the prison population would continue to increase at a rapid clip? Nonetheless, the Supreme Court's remarkable decision on juvenile LWOP in Graham v. Florida makes it hard to resist questioning the future of even adult LWOP now. In this section, I'll separately discuss Graham and a number of other recent developments that might contribute to a decline in LWOP.

\section{A. Graham and the Prospects for Constitutional Regulation}

Although the decision is barely five months old as of this writing, Graham has already inspired a great deal of expert commentary. Indeed, this issue of FSR features no fewer than nine responses to Graham. ${ }^{7}$ Although each offers its own unique insights, they share two core observations: (a) the majority in Graham adopted a new methodology for reviewing Eighth Amendment challenges to

Federal Sentencing Reporter, Vol. 23, No. I, pp. I-9, ISSN 1053-9867 electronic ISSN 1533-8363. (C) 2010 Vera Institute of Justice. All rights reserved. Please direct requests for permission to photocopy or reproduce article content through the University of California Press's Rights and Permissions website, http://www.ucpressjournals.com/reprintInfo.asp. DOI: I0.I525/fsr.20I0.23.I.I. 
noncapital sentences that appears more favorable to defendants than the Court's prior approach, but (b) the majority left many important questions unanswered, including when the new approach must be applied and how much more favorable the new approach really is. Indeed, as Richard Frase observes in his contribution to this issue, the Court seems to have left a notoriously opaque area of the law even less clear than it was before. ${ }^{8}$

The Court has long held that the Eighth Amendment includes a proportionality requirement for sentences. ${ }^{9}$ In recent years, the Court has been quite active in using this requirement as a basis for regulating capital punishment, adopting various categorical restrictions as to which defendants can be executed for which offenses. ${ }^{10}$ On the other hand, in noncapital cases, the Court has treated the proportionality requirement as so undemanding as to be nearly meaningless. ${ }^{\text {II }}$ In Graham, however, the Court for the first time employed its capital sentencing methodology to evaluate the constitutionality of a noncapital sentence. ${ }^{12}$

To be sure, as a formal matter, the basic capital methodology does not appear intrinsically more favorable to defendants than the established noncapital methodology-in a sense, all that happens is a reverse in the order of analysis. ${ }^{\mathrm{I}}{ }^{3}$ But, to defendants facing LWOP, what seems potentially quite beneficial about the Graham shift is the ability to draw on the body of precedent that has grown up in the capital sentencing area, which makes a variety of strong categorical distinctions-for example, between minors and adults, between homicide and other offenses, between the mentally retarded and the mentally fit, and between those with major and minor roles in the offense. Indeed, the first two of these distinctions were crucial in Graham itself, because the Court banned LWOP for minors who have committed nonhomicide offenses.

Based on the reasoning of Graham, a colorable constitutional argument against LWOP would seemingly apply in any case in which any two of the protected categories were present-for example, a mentally retarded minor who committed homicide, or a mentally retarded adult who committed an offense other than homicide, or a minor who was convicted of felony-murder but did not have a substantial role in the offense. Moreover, Graham can be expected to spur more frequent and more forcefully litigated Eighth Amendment challenges in noncapital cases, challenges that might result in judicial recognition of new categorical distinctions, such as between violent and nonviolent offenses, between first-time offenders and recidivists, and among the various degrees of mens rea. If courts head down the path of constitutionalizing more of the distinctions that have long been recognized in criminal codes, one could imagine the emergence of a truly robust, even intricate, set of Eighth Amendment restrictions on the use of LWOP.

Another curious aspect of Graham might also portend greater regulation of LWOP: the Court's embrace of hope as a constitutional value. This subject is the focus of Alice Ristroph's contribution to this issue. As she observes, the absence of hope of release-and hence "no chance for fulfillment outside prison walls, no chance for reconciliation with society" - marked LWOP as a distinctly harsh sentence in the majority's view. ${ }^{\text {I4 }}$ If it is cruel to deny hope to juvenile offenders, it is not clear that it is any less cruel to deny hope to similarly situated adult offenders-whether one is 15 or 50 , the rigors of prison life are likely much easier to bear if one can look forward to the possibility of regaining the trust and acceptance of one's fellow citizens.

Yet, for all of its breathtaking qualities, Graham will probably not initiate a dramatic expansion of Eighth Amendment protections. None of the recent personnel changes on the Supreme Court seem likely to alter the Court's longstanding balance of power when it comes to the Eighth Amendment. Standing in the center of an evenly divided Court, Justice Kennedy's views govern in this area. It is no accident that he authored the majority opinion in Graham, and nothing in that opinion indicates that Kennedy regrets his opinion in Harmelin v. Michigan ${ }^{15}$ —an opinion reflecting what Eva Nilsen aptly characterizes as a "facile deference to legislators" in her contribution to this issue. ${ }^{16}$

In truth, the Court took on an easy target in Graham: Juvenile LWOP inmates constitute less than 5 percent of all LWOP inmates nationally, ${ }^{17}$ and only a dozen states hold more than thirty of them. ${ }^{18}$ Moreover, as John Stinneford points out in his contribution to this issue, the legal changes in the I990s that exposed many more juvenile defendants to LWOP were driven by a "superpredator scare" that now seems to have been wildly exaggerated. ${ }^{19}$

Graham thus calls to mind the Court's modest incrementalism in addressing capital sentencing (again, with Justice Kennedy at the helm), where the Court's recent work has looked bold only in comparison to the period of extraordinary passivity that preceded it. Here, too, the Court's targets have been practices that are both relatively uncommon and seemingly connected to outmoded or illfounded beliefs. On the other hand, the Court has declined to require that killings be intentional in 
order to qualify for the death penalty ${ }^{20}$ or otherwise to bring much rigor to the way that states distinguish capital from noncapital murder. ${ }^{21}$

Doctrinally, Graham leaves it uncertain when courts should use the categorical approach in noncapital cases. (As Carol and Jordan Steiker point out in their contribution to this issue, Graham also raises questions about whether the Court might use the categorical approach less reliably in capital cases. ${ }^{22}$ ) The Court explained its use of the categorical approach in Graham by characterizing the case as involving a challenge to a "sentencing practice," instead of to a particular sentence. ${ }^{23}$ But this distinction is not likely to prove durable, because any Eighth Amendment challenge to a sentence can be easily recharacterized as a challenge to a practice. Moreover, Graham also leaves it uncertain what states must do in order to provide offenders with the requisite hope. The Court indicated that a state "need not guarantee the offender eventual release," but only "some realistic opportunity to obtain release." 24 Thus, even if Graham is extended to some subset of adults, it is possible that the hope requirement will be held satisfied by parole systems that only rarely grant release. As Rachel Barkow pointedly asks in her contribution to this issue, "[I]f the state grants parole to even a single offender, is the Court going to be prepared to second-guess all the other decisions?" 25 Finally, as Youngjae Lee highlights in his contribution to this issue, Graham implicitly raises, but fails to answer, the questions of whether and under what circumstances crime-control considerations may constitutionally justify a punishment that is excessive in relation to the offender's culpability. ${ }^{26}$ In light of the Court's Eighth Amendment track record over the past two decades, it is hard to believe that such ambiguities will be resolved decisively in favor of stronger Eighth Amendment protections.

\section{B. Fiscal Pressures and the Prospects for a Parole Renaissance}

Since 2000 , at least twenty-eight states have enhanced early-release options for prison inmates, ${ }^{27}$ largely as a result of fiscal pressures created by burgeoning prison populations. ${ }^{28}$ Against the recent backdrop of economic turmoil and stagnant government revenues, ${ }^{29}$ policymakers have found early release to be an attractive option, particularly to the extent that it can be implemented without obvious public-safety hazards. ${ }^{30}$ Thus, many early-release programs have focused on inmates who are elderly or seriously ill, ${ }^{31}$ nonviolent offenders, ${ }^{32}$ and offenders who complete designated educational or therapeutic programs. ${ }^{33}$ Similarly, many states have focused on expanding opportunities for inmates to earn "good time" credits. 34

Will such programs provide much benefit to LWOP inmates, perhaps even reintroducing the functional equivalent of parole through the back door? Although some of the new programs are designed to screen out the most serious offenders, others do make LWOP inmates eligible for release. In this issue, for instance, Gregory O'Meara discusses Wisconsin's expansion of a program in 2009 that now permits LWOP inmates to petition for release on the basis of age and infirmity. 35 However, the experience thus far in Wisconsin and many other states has been that officials, fearful of another Willie Horton, ${ }^{36}$ have been far more conservative than anticipated in granting petitions for release. ${ }^{37}$ Indeed, in some states, new early-release programs have become political lightning rods even without a high-profile failure..$^{8}$ These experiences leave considerable doubt as to whether the new early-release programs are capable of making a significant, lasting difference in the size of prison populations, and the most serious offenders with the most severe sentences seem the most likely to see their petitions denied as a result of the political headwinds.

Nor should this conservatism be surprising. After all, governors have long had the power to grant clemency based on the same criteria used in the new early-release programs, but, as Molly Gill demonstrates in her contribution to this issue, governors have virtually stopped granting clemency to anyone over the past three decades. 39

If current LWOP inmates are unlikely to see much benefit from the current fiscal crisis-indeed, they may suffer as a result of the termination or contraction of prison programming ${ }^{4 \circ}$ - perhaps fiscal pressures will at least slow the growth of the LWOP population at the front end by forcing the adoption of sentencing reforms that preclude or discourage the imposition of life terms. Such reform, however, does not seem to be a particular legislative priority at present. Although many states have indeed adopted sentencing reforms in the past couple of years, the reforms generally focus on lower-end offenders, for instance, by eliminating mandatory minimums for drug possession defendants. $4^{\mathrm{I}}$ One of the few exceptions was Texas's elimination of LWOP for juveniles, ${ }^{42}$ but, of course, the significance of that new law was much diminished by Graham.

Other states have recently created commissions or other new bodies that are charged with studying sentencing practices, ${ }^{43}$ and it is possible that such bodies will serve to focus attention on LWOP 
sentences. However, to the extent that immediate fiscal pressures continue to drive the sentencing policy agenda, LWOP reform is not likely to be a priority: Because any offenders who are diverted from LWOP are still likely to get very long sentences, any fiscal savings from front-end LWOP reforms will not be realized for many years - well beyond the time horizons of legislatures facing short-term crises. Moreover, through Apprendi v. New Jersey 44 and its progeny, the Supreme Court has made it more difficult for states to implement mandatory sentencing guidelines, which might otherwise be the most attractive tool for controlling unnecessarily long sentences.

\section{Developments in International Law}

As Dirk van Zyl Smit argues in his contribution to this issue, prospects seem good that LWOP will soon be banned in Europe as a matter of international human rights law. ${ }^{45}$ To the extent that LWOP is increasingly seen abroad as inconsistent with established norms of humane punishment, the United States may come under pressure to abandon LWOP, much as it has faced pressure to do away with the death penalty.

It is far from clear, however, that the United States is responsive to such pressures. There seems not to be much of a domestic constituency for conforming American penal practices to international norms; indeed, a much more important constituency may exist for preserving the political and cultural distinctiveness of the United States from Europe. Moreover, the fractured, federal structure of American government further diminishes the likelihood that the interest of the United States in maintaining its standing in the international community will have much effect on its penal practices: Whereas the federal government carries the nation's diplomatic responsibilities, the vast majority of criminal prosecutions are carried out in state courts under state law.

However, international developments will not necessarily prove wholly irrelevant to the future of LWOP in the United States. For instance, other nations may take LWOP-eligibility into account when deciding whether to honor American extradition requests, as sometimes has been done already with respect to death-eligible offenders. Moreover, the Supreme Court's recent Eighth Amendment cases, including Graham, have routinely cited international law. ${ }^{4}$ However, such references to international sources are controversial-Jessica Olive and David Gray provide an originalist defense of the practice in their contribution to this issue 47 -and, in any event, often seem little more than an afterthought in the Court's analysis. It is hard to imagine international rejection of LWOP driving the Court beyond the modest incrementalism suggested by Graham itself.

\section{Decline of the Death Penalty}

The American death penalty now seems in long-term decline. The number of people executed decreased nearly every year from I999 through 2008 , falling from 98 to 37 in that time. ${ }^{8}$ Likewise, the number of inmates received under sentence of death decreased nearly every year from I994 through 2008 , falling from 328 to III. 49 Moreover, in the past three years, two states (New Jersey and New Mexico) have repealed the death penalty, whereas a third (Maryland) substantially restricted the circumstances in which it can be imposed..$^{\circ}$

It is not clear whether or how these developments will affect LWOP, but one can hypothesize at least two possible consequences. First, at the level of legislative policymaking, the decline of the death penalty may diminish the support of liberal reformers for LWOP as an alternative to capital punishment, and perhaps even lead some death penalty abolitionists to refocus their reform efforts on rolling back LWOP as a more practically significant policy objective. Second, at the level of individual cases, the diminished availability of capital punishment (as a matter of law in some jurisdictions and a matter of practice in others) will reduce the pressure on murder defendants to accept plea deals that may result in LWOP sentences.

At present, though, there seems no reason to think that either potential effect will have dramatic consequences for the frequency of LWOP sentences, at least in the near term. For instance, neither of the two states that recently abolished capital punishment actually used it very much; ${ }^{\mathrm{I}}$ nor does either state have a sizeable LWOP population. ${ }^{22}$ If death penalty abolitionists continue to have their greatest success in such states, there is likely to be little resulting reduction in national LWOP rates.

\section{Should the Decline of LWOP Be Welcomed?}

Assuming at least a period of slow decline in the prevalence of LWOP, ought the shift to be regarded as a positive development? LWOP is normally debated in relation to capital punishment, with commentators considering whether LWOP offers an adequate alternative to the more severe (but more 
costly to administer) punishment of death. Here, I'd like to consider LWOP from the other side of the severity scale. In light of the decline of the death penalty and the growth of LWOP, it is time to ask whether LWOP offers a justifiable alternative to the less severe (but less costly) punishment of life with possibility of parole. As is common when considering the appropriateness of particular punishments, I'll focus separately on whether LWOP can be justified on crime-control grounds and retributive grounds.

\section{A. Crime Control}

LWOP might be justified on crime-control grounds, but it is far from clear that LWOP actually offers any marginal benefits relative to life with parole. To be sure, many-perhaps most—of those sentenced to LWOP are dangerous, violent offenders who warrant long-term incapacitation. ${ }^{53}$ Yet, as

Ashley Nellis points out in her contribution to this issue, offenders tend to mature out of their criminal behavior, and the available research indicates that older, longtime inmates present a relatively low recidivism risk upon release. 54 In light of these considerations, as well as the declining physical capacity that normally goes along with aging, the need for incapacitation may only rarely justify imprisonment all the way to the end of an offender's life.

To favor LWOP over life with parole on incapacitation grounds, one would have to assume that parole boards cannot reliably determine when inmates are safe to release and tend to err on the side of releasing inmates too early. Although it is true that dangerousness determinations involve too many human variables to reach a high level of precision, it does not seem that parole boards have in recent years been especially generous to inmates. 55 And a legislature that is nonetheless distrustful of the judgment of parole officials might ensure a conservative approach by mandating the use of parole guidelines built around objective indicia that offer a high level of confidence of nondangerousness.

LWOP might alternatively be justified on deterrence grounds, but the case for crime-control benefits on this theory is also less than compelling. Whether the death penalty deters continues to be uncertain and hotly debated..$^{6}$ It is hard to imagine that LWOP, typically considered a less severe penalty than death, would have any clearer deterrence benefits.

From the viewpoint of a prospective criminal weighing the potential pains of punishment, the difference between life with and without parole may seem remote and speculative: Either sentence involves many years in prison, and it is hard to predict what parole practices will be in the future and to what extent nonparole release alternatives, such as clemency and compassionate release, will be available. Unless the parole board is perceived to be extremely lenient, life without parole may not seem much more of a threat than life with. Moreover, as against the potential deterrence benefits of LWOP, one must also consider the possibility that the resources used to incarcerate LWOP inmates long past their period of dangerousness might be put to better crime-control use by expanding rehabilitative programs or increasing the capacity of law enforcement agencies to apprehend and prosecute a greater number of offenders.

\section{B. Retribution}

The stronger arguments for LWOP may be retributive in nature. A common form of retributive thinking aims for some sort of equivalence of suffering between victim and offender, in the spirit of "an eye for an eye." In his contribution to this issue, Robert Blecker shows the intuitive appeal of this approach. ${ }^{57}$ Moreover, if punishment is best thought of as payback (to use Blecker's word), one can imagine a colorable case for LWOP at least for murderers: If you intentionally take the life of another person, then the state takes your life away-not literally, of course, but your life will nonetheless be irrevocably changed through a permanent loss of certain basic rights that might be thought of as a sort of civil death. Viewed this way, there is an appealing symmetry between LWOP and the underlying offense. Indeed, by like reasoning, LWOP might be seen as an appropriate response to lesser homicides and to other seriously traumatizing crimes (e.g., forcible rape) that seem in some metaphorical sense to take the victim's life away.

But, as Blecker argues, if the aim is payback, LWOP does not in the end seem quite up to the task. Life goes on for LWOP inmates. They adapt to prison. They are able to acquire privileges through good behavior. They enjoy recreational opportunities, a social life, and family visits. They receive food, shelter, and medical care at state expense. This is not to say that prison life is preferable to life outside, but if severe, long-term suffering is the goal, then LWOP is likely to disappoint. 
Indeed, surveys of prison inmates show that after a few difficult weeks at the outset, positive feelings increase and negative feelings decrease steadily over a period of years and may eventually reach the normal range..$^{8}$ By contrast, research on life after even relatively short stays in prison suggests that ex-inmates typically face extraordinary, long-term challenges to reintegration and a return to the level of well-being they enjoyed before prison. 59 Thus, judging by the amount of suffering imposed, life with parole may not actually be that much more lenient a sentence than life without parole.

One might respond, as Blecker does, by rejecting LWOP (at least for the most serious offenders) in favor of the death penalty or perhaps some new form of incarceration that is better designed to induce suffering. His argument is provocative, but for present purposes I am assuming that nothing more severe than LWOP is on the table-my interest is in considering whether LWOP can be justified as the ultimate sentence in lieu of life with the possibility of parole.

In any event, another possible response to Blecker's observations about LWOP would be to abandon the whole project of aiming for a particular degree of suffering through punishment—a project that might now be seen as futile or worse. The research on prison adaptation reveals the daunting psychological complexity of suffering, which seems all the more difficult to manage when one takes into account how differently individuals respond to incarceration. ${ }^{60}$ Moreover, as James Whitman has argued, there seems something morally troubling and potentially dangerous about approaches to punishment that aim for suffering; he observes a tendency for retributive emotions to degenerate into simple vengefulness, notwithstanding an initial commitment to punish in a restrained, proportional fashion. ${ }^{61}$

Other approaches to retribution seem more responsive to such concerns. In particular, some retribution theorists argue that punishment should not aim for some particular degree of suffering per se, but should instead focus on communicating a message to the offender-a message of condemnation for wrongful conduct, to be sure, but one that also embodies respect for the offender as a fellow human being and member of the political community. Although calibrating penal severity in a proportionate way is part of the communicative project, shifting the focus from suffering to communication nonetheless has important implications. Thus, for instance, Dan Markel, a leading theorist in this area, contends in his contribution to this issue that juveniles may not be suitable subjects of retributive blaming because their lesser cognitive capabilities mean that they may not be competent to understand adequately the meaning of their punishment. ${ }^{62}$

Assuming a fit interlocutor for the state's message of condemnation, however, can LWOP be justified in communicative terms? The answer depends, in part, on what the social meaning of LWOP is as a form of punishment-what exactly does sentencing a person to life without parole communicate?

R.A. Duff has argued that imprisonment sends a very harsh message indeed:

The most salient aspect of imprisonment is that it excludes the offender. . . The message of imprisonment is that the offender has not just damaged or threatened, but has broken the normative bonds of community. He has made it impossible for us to live with him in the ordinary community of fellow citizenship unless and until he has undergone this penitential punishment. ${ }^{6}$

In Duff's view, imprisonment is a reasonable response only "to the most serious wrongs, which directly flout the community's most central or essential values." ${ }_{4}$ Although Duff cautions that there is no "determinate or fixed" answer to what constitutes the set of most serious crimes warranting imprisonment, ${ }^{6}$ any crime involving an intent to kill or otherwise to inflict serious bodily injury would seem a strong candidate. Property or drug crimes less clearly fit the bill, even when perpetrated by recidivists. ${ }^{66}$

But, even for violent crime, this line of thinking has provided only a justification for imprisonment. What about LWOP? On the one hand, the severity of any punishment must be assessed in relative terms against a backdrop of existing norms. In early-twenty-first-century America-where incarceration is routine, prison terms are commonly meted out in years and even decades, and parole is often perceived as easy to obtain-any term of imprisonment less than LWOP arguably fails to send a sufficiently strong message of condemnation in response to the very worst offenses.

On the other hand, LWOP sends a message of permanent exclusion from what Duff calls the ordinary community of fellow citizenship. This message seems hard to square with an approach to punishment (like Duff's) that, at bottom, seeks to preserve, not destroy, the bonds of community. ${ }^{67}$ 
Moreover, one might also be concerned that LWOP expresses the view that the offender is beyond redemption or rehabilitation. Catherine Appleton and Bent Grøver have emphasized this concern in their critique of LWOP, ${ }^{68}$ amplifying a common theme in the international jurisprudence on LWOP. ${ }^{69}$ If the capacity for change and moral growth is regarded as a core attribute of humanity, then LWOP might be seen as a profoundly inhumane punishment—as a denial of the offender's capacity to live a fully realized human life.

In the end, these questions of social meaning seem sufficiently indeterminate that it is difficult to conclude that LWOP can never be retributively justified. However, a good case can be made that LWOP ought at least to be limited to the sorts of serious homicides to which the death penalty is constitutionally restricted—given the morally troubling messages that are potentially communicated by LWOP, it ought not to be used unless the offender's crime is so serious that anything short of LWOP would clearly seem lacking in proportionality.

\section{Conclusion}

Against a backdrop of intense fiscal pressure, an emerging international consensus against LWOP, and long-term decline in use of the death penalty, Graham may mark the end of the growth phase of LWOP. Indeed, although dramatic reductions in the LWOP inmate population seem unlikely any time soon, it is possible that LWOP will enter a period of slow decline that echoes the recent history of the death penalty. If this trend means fewer old or infirm inmates spending their final years in prison for nonhomicide offenses, then such a period of decline would almost certainly be a positive development. Moreover, if the decline of the death penalty and LWOP were part of a broader deescalation of penalties, the United States might finally move beyond the point where sentences less than LWOP seem even arguably inadequate for the most serious offenses.

\section{Notes}

* Thanks to Brian Burkowicz for helpful research assistance.

1 Ashley Nellis \& Ryan S. King, The Sentencing Project, No Exit: The Expanding Use of Life Sentencing in America 9-10 (2009).

2 Carol S. Steiker \& Jordan M. Steiker, Opening a Window or Building a Wall? The Effect of Eighth Amendment Death Penalty Law and Advocacy on Criminal Justice More Broadly, 11 U. PA. J. Const. L. 155, 158 (2008).

3 Graham v. Florida, 130 S. Ct. 2011 (2010).

4 See infra Part I.B.

5 See infra Part I.C.

6 See infra Part I.D.

7 Rachel E. Barkow, Categorizing Graham, 23 Fed. Sent. ReP. 49 (2010); Richard S. Frase, Graham's Good News-and Not, 23 Fed. Sent. Rep. 54 (2010); Youngjae Lee, The Purposes of Punishment Test, 23 Fed. Sent. ReP. 58 (2010); Dan Markel, May Minors Be Retributively Punished After Panetti (and Graham)?, 23 FED. SENT. ReP. 62 (2010); Eva S. Nilsen, From Harmelin to Graham_Justice Kennedy Stakes Out a Path to Proportional Punishment, 23 Fed. Sent. Rep. 67 (2010); Jessica Olive \& David Gray, A Modest Appeal for Decent Respect, 23 Fed. Sent. Rep. 72 (2010); Alice Ristroph, Hope, Imprisonment, and the Constitution, 23 FEd. SENT. ReP. 75 (2010); Carol S. Steiker \& Jordan M. Steiker, Graham Lets the Sun Shine in: The Supreme Court Opens a Window Between Two Formerly Walled-Off Approaches to Eighth Amendment Proportionality Challenges, 23 FED. SENT. REP. 79 (2010); John F. Stinneford, Evolving Away from Evolving Standards of Decency, 23 FED. SENT. REP. 87 (2010).

8 Frase, supra note 7.

9 See, e.g., Weems v. United States, 217 U.S. 349, 367 (1910).

10 See, e.g., Kennedy v. Louisiana, 128 S. Ct. 2641 (2008) (banning death penalty for rape of a child); Roper v. Simmons, 543 U.S. 551 (2005) (banning death penalty for juveniles).

11 See, e.g., Ewing v. California, 538 U.S. 11 (2003) (upholding sentence of twenty-five years to life for theft of golf clubs).

12 Graham, 130 S. Ct. at 2022-23.

13 In the noncapital cases, the prevailing approach involved first a "threshold comparison" of the gravity of the offense and the severity of the sentence and then a more objective comparison of the sentence imposed with sentences in other cases and across jurisdictions. Id. at 2022. In capital cases, by contrast, the Court begins with an objective, interjurisdictional comparison and then moves to an "independent judgment" regarding the culpability of the offender and the severity of the punishment. Id. at 2023, 2026.

14 Ristroph, supra note 7 (quoting Graham, 130 S. Ct. at 2032).

15501 U.S. 957 (1991).

16 Nilsen, supra note 7.

17 NeLlis \& KING, supra note 1 , at 19.

18 Id. at 18

19 Stinneford, supra note 7.

20 Tison v. Arizona, 481 U.S. 137, 152 (1987). 
21 See, e.g., Arave v. Creech, 507 U.S. 463 (1993).

22 Steiker \& Steiker, supra note 7.

23130 S. Ct. at 2022-23.

24 Id. at 2034.

25 Barkow, supra note 7.

26 Lee, supra note 7.

27 See Michael M. O'Hear, Beyond Rehabilitation: A New Theory of Indeterminate Sentencing (forthcoming).

28 See Christine S. Scott-Hayward, Vera Institute of Justice, The Fiscal Crisis in Corrections: Rethinking Policies AND PRACTICES 3 (2009) ("Second only to Medicaid, corrections has become the fastest growing general fund expenditure in the United States. . . . In FY2008, the most recent year data are available, states spent an estimated $\$ 47$ billion of general funds on corrections, an increase of 303 percent since 1988.").

29 See id. ("Forty-three states were facing an aggregate budget gap in FY2009 of more than \$100 billion. . . .").

30 Id. at 9-11. See also Judith Greene \& Marc Mauer, The Sentencing Project, Downscaling Prisons: Lessons from Four StATES 34-36 (2010) (describing Michigan Prisoner Reentry Initiative, in which Michigan Department of Corrections recently achieved increased parole approval rates following institution of measures designed to increase confidence of parole board, including data-driven risk assessment and improved case management of parolees).

31 See, e.g., Tina Chiu, Vera Institute for Justice, It's About Time: Aging Prisoners, Increasing Costs, and Geriatric RELEASE 9-10 (2010) (describing Alabama and Virginia programs).

32 Ryan S. King, The Sentencing Project, The State of Sentencing 2007, at 13 (2008) (describing Arkansas pro. gram).

33 See, e.g., Alison lawrence, National Conference of State Legislatures, Cutting Corrections Costs: Earned Time Policies for State Prisoners 6 (2009) (describing Kansas program).

34 See, e.g., id. at 4 (describing Colorado program).

35 Gregory J. O'Meara, Compassion and the Public Interest: Wisconsin's New Compassionate Release Legislation, 23 Fed. Sent. Rep. 33 (2010).

36 Willie Horton, the convicted murderer who committed another violent crime while on a weekend furlough from a Massachusetts prison, was the subject of a highly effective political ad in opposition to the presiden. tial candidacy of Massachusetts Governor Michael Dukakis in 1988. KathleEn Hall Jamieson, DiRTY Politics: Deception, Distraction, and Democracy 15-42 (1992).

37 See, e.g., Ben Poston, Sentencing Reform Results Fall Short, MiLw. J. Sentinel, July 10, 2010, at A1 (discussing Wisconsin); Cara Buckley, Law Has Little Effect on Early Release for Inmates, N.Y. Times, Jan. 30, 2010, available at http://www.nytimes.com/2010/01/30/nyregion/30parole.html (discussing California, Alabama, and New York).

38 See, e.g., Monica Davey, As Budget Cuts Free Prisoners, States Face a Backlash, N.Y. TımES, March 4, 2010, available at http://www.nytimes.com/2010/03/05/us/05parole.html (discussing Oregon, Illinois, Colorado, California, and Michigan).

39 Molly M. Gill, Clemency for Lifers: The Only Road Out Is the Road Not Taken, 23 Fed. Sent. Rep. 21 (2010).

40 For fiscal year 2010, at least nine states have cut health services for prisoners, seven have cut food services, and twenty have eliminated or reduced other programs, or discontinued or renegotiated contracts for pro. gramming. SCOTT-HAYWARD, supra note 28, at 5.

41 See, e.g., Nicole D. Porter, The Sentencing Project, The State of Sentencing 2009: Developments in Policy and Practice 4-5 (2010) (discussing reforms in Minnesota, New York, and Rhode Island).

42 Id. at 16.

43 SCOTT-HAYWARD, supra note 28 , at 10.

44530 U.S. 466 (2000).

45 Dirk van Zyl Smit, Outlawing Irreducible Life Sentences: Europe on the Brink?, 23 FED. Sent. REP. 39 (2010).

46130 S. Ct. at 2033-34.

47 Olive \& Gray, supra note 7.

48 Tracy L. Snell, U.S. Dep't of Justice, Capital Punishment, 2008-Statistical Tables tbl. 15 (2010), available at http://bjs.ojp.usdoj.gov/content/pub/pdf/cp08st.pdf. Preliminary numbers for 2009, however, do indicate at least a small upswing in executions.

49 ld. tbl. 14

50 PORTER, supra note 41 , at 9.

51 SNELL, supra note 48, tbl. 9 (showing that New Mexico and New Jersey had between them executed only one person since 1977).

52 NelLis \& KING, supra note 1 , at 8 (showing that New Mexico and New Jersey have between them forty-six LWOP inmates).

53 Although many sentenced to LWOP have criminal histories suggestive of propensities toward violence, in light of the availability of LWOP in many jurisdictions for drug trafficking offenses and third-strike convictions, it cannot be assumed that all LWOP inmates are violent. Catherine Appleton \& Bent Grøver, The Pros and Cons of Life Without Parole, 47 BRIT. J. CRIminology 597, 599 (2007). In all, thirty-seven states make LWOP available for nonhomicide offenses. Ashley Nellis, Throwing Away the Key: The Expansion of Life Without Parole Sentences in the United States, 23 FED. SEnT. Rep. 27 (2010).

54 Nellis, supra note 53.

55 See Joan Petersilia, Reforming Probation and Parole in the 21st Century 111-12 (2002) (discussing decline in percentage of cases in which parole has been granted since 1980s). 
56 John J. Donohue \& Justin Wolfers, Uses and Abuses of Empirics in the Death Penalty Debate, 58 STAN. L. REV. 791 (2005).

57 Robert Blecker, Less Than We Might: Meditations on Life in Prison Without Parole, 23 Fed. Sent. ReP. 10-20 (2010).

58 John Bronsteen et al., Happiness and Punishment, 76 U. CHI. L. REv. 1037, 1048 (2009).

59 Id. at 1054.

60 Adam J. Kolber, The Subjective Experience of Punishment, 109 Colum. L. Rev. 182 (2009).

61 James Q. Whitman, Making Happy Punishers, 118 HARV. L. REV. 2698, 2716-18 (2005).

62 Markel, supra note 7.

63 R.A. Duff, Punishment, Communication, and Community 149-50 (2001).

64 Id. at 150-51.

65 Id. at 151.

66 For a helpful discussion of the appropriate role of criminal history in communicative forms of retributivism, see id. at $167-70$.

67 Id. at 151.

68 Appleton \& Grøver, supra note 53, at 612.

69 Id. at 609-11. 